\title{
Complexities and Dilemmas in the Sharing Economy The Uber Case
}

Christine Boshuijzen-van Burken ${ }^{1}$, Darek M. Haftor ${ }^{2}$

${ }^{1}$ Department of Informatics, Linnaeus University, christine.boshuijzenvanburken@lnu.se

2Department of Informatics, Linnaeus University, darek.haftor@lnu

\begin{abstract}
By taking Uber as a case, we take a practice focus, in-depth analysis of the sharing economy. The business model that is typical for the sharing economy is based on using underutilized goods by private persons through digital technologies. In this paper, we bring together the complex reality of the sharing economy with a philosophical tool for analyzing normative issues. We listed a number of issues that were raised in debates, protests and court files that creates tensions and dilemmas for regulators and established industries and categorized them in a table with potentially normative aspects of the issues.

The categorization was done through a multi-aspectual analysis. It revealed that next to several public complaints and worries, also other, presumably overlooked aspects, may give rise to moral issues and dilemmas at a deeper level.
\end{abstract}

Key words: sharing economy, multi-aspectual analysis, Uber, digital technologies, normative analysis, Dooyeweerd

(C) 2015 Christine Boshuijzen-van Burken et al. This is an Open Access article distributed under the terms of the Creative Commons Attribution-NonCommercial 4.0 International License (http://creativecommons.org/licenses/by-nc/4.0/), permitting all non-commercial use, distribution, and reproduction in any medium, provided the original work is properly cited.

http://dx.doi.org/10.15626/dirc.2015.04 


\section{Introduction}

In her essay "Debating the sharing economy" (2014), Juliet Schor raised the following question: "[...] will the sharing economy be the disruptive, worldchanging innovation its proponents expect? And if it is, will it change the world for the better? It is too early for definitive answers to these questions, but important to ask them." In the wake of a growing amount of academic literature ${ }^{1}$ on the application based platforms and in the heat of public debates and street riots over instances of what is publicly known as the sharing economy, Schor raised an important question in the realm of normativity and ethics. In this paper, we aim to bring together the empirical reality of the sharing economy as reported in international newspaper articles and on websites with a philosophical tool for analyzing normative issues and articulating a range of dilemmas. By taking Uber as a case, we start from a practice focus, in-depth analysis of the sharing economy.

Several authors gave a definition of the sharing economy, for example, Botsman $(2015)^{2}$ or Meelen and Frenken $(2015)^{3}$. Although the term "sharing" can be contested, because it only partially captures some aspects of activities which entail employment of a single good for multiple purposes (e.g., using a vehicle both for an owner's personal needs and to transport paying passengers in the case of Uber), we will use the term sharing economy for a range of activities in which private goods or services are rented or lended out through online platforms.

Business models based on underutilized goods by private persons have existed for a longer period, but since digital technologies are used to connect private supply and demand on an unprecedented scale, the sharing economy has taken off. The key efficiencies generally do not come from "sharing" but from the business model that platforms facilitate, including casual service providers who avoid the fixed cost and, often, regulation associated with traditional service. (Edelman \& Geradin, 2015) In this paper, we look at the case of Uber, which is an example of a shared mobility business model.

We start with a general overview of Uber followed by its activities have since its start evoked many emotions, debates and in some places have been banned altogether. We categorize these reactions and further analyse Uber by making use of the multi-aspectual analysis. We conclude with insights from the Uber case that are relevant for the sharing economy at large.

\footnotetext{
${ }^{1}$ Smolka and Hienehrt (2014) - provide a helpful literature overview on the sharing ecomomy.

2 "Sharing Economy: An economic system based on sharing underused assets or services, for free or for a fee, directly from individuals." (Botsman 2015)

3 "the sharing economy is consumers (or firms) granting each other temporary access to their under-utilized physical assets ("idle capacity"), possibly for money." (Meelen and Franken 2015)
} 


\section{The Uber case}

According to Uber itself, Uber is a company which connects riders to drivers through their applications (apps) on smartphones, thus making cities more accessible, opening up more possibilities for riders and more business for drivers, according to Uber's website. Uber was founded as "UberCab" by Travis Kalanick and Garrett Camp in 2009, after the two had been brainstorming about new ideas for start-ups (Kalanick, 22 December 2010). Uber's mobile app for iPhones and Android phones was launched in San Francisco in 2010 and after receiving venture funding its total funding amount was almost $\$ 50$ million in late 2011 . It currently operates in 68 countries (Uber.com, December 2015) and cities in the world and was valued at $\$ 40$ billion in May 2015 (Tam \& de la Merced, Michael J., 2015).

Uber's uniqueness is that it fills a gap where regular taxis are considered not reliable, slow or expensive and public transport is not very well available. Depending on the country and city, Uber's business models differ. The list below states five types of vehicle services, which can be chosen by the customer, depending on the location:

- Black Car - This is Uber's original service. Black Car will send a high-end sedan to the customer's location, with seating for up to four people.

- Taxi - This setting calls a taxi that has an agreement with Uber. These taxis are much like any normal taxi, except that customers can pay through the app.

- UberX/UberPOP - This setting sends an everyday car to the customer's location with seating for up to four people. It is Uber's budget option.

- SUV - This setting sends an SUV to the customer's location with seating for up to 6 people. This option is significantly more expensive than the Black Car service.

- LUX - This setting sends a high-end luxury car to the customer's location with seating for up to four people. This is Uber's most expensive service.

For the purpose of this paper, we focus on the UberPop, since this version has created most tensions and dilemmas, so where we write Uber, we mean this specific version of Uber where private cars are used by people without a taxi-license. Drivers as well as passengers create an account through the Uber smartphone application, where passengers will be asked for their name, mobile number, email, language, and billing information, including a valid credit card (see Uber.com). Passengers who have installed the Uber app on their smartphone allows them to see, on an interactive map, where the nearest Uber driver is. Passengers request a 
ride through the app and drivers can accept the ride by simply clicking a button in the app. No bookings can be made in advance and payments cannot be done in cash, but are automatically taken from the credit card through the app. Uber drivers receive a weekly payment, based on the amount of rides in that specific week. In order to guarantee passengers' safety, Uber performs a background check, which is conducted through a private company called Hirease. The thoroughness of the backup check for drivers differs per country, since there are different laws and ways to access private information about drivers. Arguably, the backup check for Uber drivers is not as thorough as the one performed on regular taxis in, for example, California, but it may be better than in some other countries (Lane, 25 April 2014). To ensure good quality of their service, Uber uses a rating system, through which passengers rate their drivers to advice potential passengers.

A critical reader could ask the question: so what is different with Uber in comparison with the traditional informal taxi business? Several authors have named key differences of application based companies compared with traditional companies in the same market segment. For example, Munger (2015), argues that the key difference is transaction costs, Friedman (2013) argues that trust is what has changed the game and Witt et al. (2015) argue that it is solely productivity gain through efficient use of existing resources. It may be clear that the difference between the informal taxi sector and Uber is, amongst others, its scale and the scope of effects and the profound influence of technology on the economic trend. Uber challenges old regulatory frameworks from New York to Dubai and from Amsterdam to Shanghai because it operates at local markets by a global information system. This is in stark contrast with the traditional taxi business, which has been under remarkably little change throughout its entire history. A contemporary taxi has a taxi meter (introduced in 1897), a twoway radio (circa 1940), and maybe a GPS device (Downes, 2 June 2013). In many places the taxi industry is highly regulated, for example, in order to control how many vehicles operate within the sector, how they are geographically distributed, what the working hours of drivers should be, how fares are charged, and what schedules should look like. (Slavnic 2011) With the arrival of taxi networking companies such as Uber, new technologies as well as new norms and rules for the practice of taxi businesses come into existence. This leads to dilemmas, as we will show in the next section.

\section{Dilemmas and Normative Issues}

Many people have protested against Uber, but what is it about this company that bothers so many, such as local governments, taxi unions, individual taxi drivers and insurance companies? Below we listed a number of issues that were raised in debates and protests and that were reported in several newspapers in countries in which Uber is active. Another source of information was a range of websites on technology, businesses, the sharing economy or politics. We look at any potentially normative aspects of the issues and the dilemmas this gives rise to. 
a. Uber takes jobs from taxi industry.

In many cities, protests from taxi drivers were held. Regular taxi drivers from the traditional taxi industry complain that Uber floods the market with drivers and cheap fares, taking away customers in a market where competition is high already. "UberX is simply an 'imitation taxi service' that is illegal and taking jobs away from legitimate taxi services". (Adhikari, 2015)

Which norm is violated here and if so, is there also a moral issue at stake? The dilemma with the taxi-industry is that it is highly regulated in the majority of cities where Uber operates. Leaving the regulation out of sight and pretending, for the sake of the argument, that the taxi business is a free market, leads to the following reasoning: It is in line with economical norms to enter an existing market and start a competitive business, according to a new business model, such as Uber does. Economic systems, with inherent norms to safeguard its economic sustainability are not necessarily violated by adding higher supply. Therefore, from a purely economic stance, there is no moral issue or dilemma at stake.

\section{b. Uber does not comply with safety measures for the transportation sec- tor.}

Dean Baker claims the new sharing is "largely based on evading regulations and breaking the law" and subjects consumers to a substandard, possibly unsafe product. (Baker, 27 May, 2014)

Governments have taken up responsibilities with regard to public safety and therefore, rules and regulations are in place, also for the transportation sector. However, there is a basic tension between government regulation and free markets, between public interests and private autonomy, and Uber challenges this basic tension with its new business model, creating dilemmas for regulators. Uber claims that it does not need to abide by the regulations for safety, because it sets its own safety standards and combines this with a two way review system whereby drivers rate passengers and passengers rate drivers with respect to:

- Arrival time

- Professionalism

- Driving

- Trip route

- Car quality

- Other

(see www.uber.com/safety) 
Clearly this is a case of norm-violation, namely the violation of safety norms that are set by governments. Uber states that this does not mean that they do not care about safety norms, but that they have created their own safety norms. According to Uber, safety is a high priority. ${ }^{4}$ The main difference between Uber's safety guarantee system and governmental safety system is that governments have a top-down approach with a punishment system while Uber uses a bottom up approach with a self-sanctioning and reward system. Governments, or an external party, check if taxi-drivers comply with the regulations and if not, sanctions follow, often in a zero tolerance policy. The underlying normative questions concerned with the safety regulations are: who defines what safe is, who and how should safety norms be checked? Is it morally wrong or right to reject an existing regulatory system and replace it with your own rules and norms and a different system to check safety? How does safety relate to responsibility? These are complex questions which create potential dilemmas for regulators and developers of business models in the sharing economy.

\section{c. Uber does not comply with licensing regulations for the transportation} sector.

Uber has been under attacks in many cities, since it does not have the licenses that are needed for commercial use of vehicles (see Taylor, 9 December 2014) and openly called regulations for the taxi industry 'outdated' (see for example open letter to Uber 2015 Boise Mayor and Council Open Letter $^{5}$ (Kraan \& van Hoek, 2014) and (MacMillan, 29 January 2015)). One of the problems with the licensing issue is that a complete 'licensing industry' around the taxi business has evolved. The taxi industry may have become an overregulated sector and it is often unclear for the taxi drivers what the regulation is good for. Licenses are in place for driving skills, social skills (i.e. how to deal with aggressive customers), first aid and professionalism. ${ }^{6}$ These norms have emerged from within as well as outside of the taxi business.

\section{d. Uber tracking raises privacy concerns.}

The most disturbing feature that Uber has developed is its so-called 'God View', which invaded people's privacy by tracking them. (Isaac,

\footnotetext{
${ }^{4}$ https://support.uber.com/hc/en-us/articles/201950566-What-is-the-Safe-Rides-Fee-

5 https://blog.uber.com/wp-content/uploads/2015/02/BoiseMayorandCouncilOpenLetter.pdf, http://blogs.wsj.com/digits/2015/01/29/uber-laws-a-primer-on-ridesharingregulations/?KEYWORDS=uber

${ }^{6}$ See for example www.ondernemersplein.nl/stappenplan/taxi-bedrijf-starten for the steps involved in starting a taxi business in the Netherlands.
} 
2015; Suster, 22 November 2014; Weisse \& Guynn, 2014). Employees at some positions in the company can use the 'God View', which provides them insight in customer's individual driving behavior and which can thereby potentially harm customer's privacy. This is a potential violation of privacy norms, which relates to the fact that Uber builds up large amounts of customer data, which can easily be used or sold for additional purposes. This potentially creates a moral dilemma with regard to privacy on the side of Uber customers (who provide privacy information) as well as for Uber.

\section{e. Uber does not take responsibility for their drivers nor for their pas- sengers.}

Responsibility questions can be asked with regard to several distinct areas in the Uber practice. Kalamar (13 May 2013) coined the term "sharewashing," to highlight that platforms shift risk onto employees under the guise of "sharing". It can be argued that Uber misleads drivers, because it does not inform drivers about the fact that an insurance policy of a privately owned car does not apply in commercial cases. Insurance policies are based on ownership, not on usage ${ }^{7}$. Another example of misleading behavior is that Uber does not inform their drivers about the criminal record that follows from the fine of illegal commercial driving. Uber pays the fines on behalf on the drivers, but Uber cannot erase the drivers' criminal records (Kraan \& van Hoek, 2014; Sharma, 2015). Legal responsibility is often in place in the online platforms in the sharing economy, but little attention goes to moral responsibility.

The issues stated in the list above are some of the many expressions of contentiousness over Uber's way of operating in the market. The question we have asked ourselves is: which of the above issues form the real dilemmas and are not merely superficial problems, but may be troubling even in a moral sense?

In the next section we address this question, by making use of multi-aspectual analysis.

\section{Multi-aspectual analysis}

The philosophical background for the multi-aspectual theory comes from Herman Dooyeweerd, a Dutch philosopher who initially developed his theory in the late 1930's. Basically, what Dooyeweerd claims is that reality presents itself in a way 
that it can be analyzed in terms of 15 aspects or modes of existence (Dooyeweerd, 1953). Those aspects are listed in Table 1.

Any entity exists in all of these modes: it has a numerical existence, a spatial, a kinematical, etcetera. The multi-aspectual analysis applies to entities (things, events) and therefore it can be applied to the novel entity Uber. The public complaints and worries have been inserted in the table below, in order to classify them as well as to discover potentially overlooked aspects that may give rise to moral issues and dilemmas at a deeper level.

TABLE 1. Multi-aspectual analysis and normative issues in the Uber case (inspired by De Vries (2005) and by Bergvall-Kåreborn (2002))

\begin{tabular}{|c|c|c|}
\hline Aspect & Public Complaint or Worry & $\begin{array}{l}\text { Relevant but over- } \\
\text { looked aspect }\end{array}$ \\
\hline 1. Numerical & Takes jobs away & \\
\hline 2. Spatial & Floods the market & \\
\hline 3. Kinematical & & $\begin{array}{l}\text { Uber is quicker in } \\
\text { use (short pickup) }\end{array}$ \\
\hline 4. Physical & & \\
\hline 5. Biotic & $\begin{array}{l}\text { Masks capitalists with sustainability } \\
\text { arguments }\end{array}$ & $\begin{array}{l}\text { Contradicts sustain- } \\
\text { ability: more cars on } \\
\text { the road? }\end{array}$ \\
\hline 6. Psychic/sensitive & Privacy & Trendy to take Uber \\
\hline 7. Logical/analytical & & $\begin{array}{l}\text { Uber based on algo- } \\
\text { rithms }\end{array}$ \\
\hline $\begin{array}{l}\text { 8. Histori- } \\
\text { cal/formative }\end{array}$ & & $\begin{array}{l}\text { Uber and regular taxi } \\
\text { have different forma- } \\
\text { tive aspect }\end{array}$ \\
\hline 9. Symbolic/linguistic & & $\begin{array}{l}\text { Digital literacy is } \\
\text { required (bias to- } \\
\text { wards certain social } \\
\text { groups) }\end{array}$ \\
\hline 10. Social & $\begin{array}{l}\text { Digs up dirt on journalist } \\
\text { Behaves immature }\end{array}$ & \\
\hline 11. Economic & $\begin{array}{l}\text { Floods the market } \\
\text { Surge-pricing not fair } \\
\text { Margins are too high }\end{array}$ & $\begin{array}{l}\text { Creates job opportu- } \\
\text { nities }\end{array}$ \\
\hline 12. Aesthetic & & $\begin{array}{l}\text { Website Uber vs } \\
\text { regular aesthetically }\end{array}$ \\
\hline 13. Juridical & $\begin{array}{l}\text { Lacks taxi licenses } \\
\text { Background checks } \\
\text { Waivers responsibility }\end{array}$ & $\begin{array}{l}\text { Waivering responsi- } \\
\text { bility affects bus- } \\
\text { siness model nega- } \\
\text { tively (cf Malhotra } \\
\text { and Van Alstyne }\end{array}$ \\
\hline
\end{tabular}




\begin{tabular}{|l|l|l|}
\hline 14. Ethical & & 2014) \\
& $\begin{array}{l}\text { Book \& Cancel competitors } \\
\text { Waivers responsibility (care) } \\
\text { Customer raped } \\
\text { Fatal accident } \\
\text { Disruptive algorithm for competitor } \\
\text { Privacy concerns } \\
\text { Misleads drivers (w.r.t. insurance) }\end{array}$ & $\begin{array}{l}\text { Biased towards } \\
\text { smartphone users } \\
\text { (neglects, e.g., el- } \\
\text { derly, poor people) }\end{array}$ \\
\hline 15. Pistic & $\begin{array}{l}\text { Safety regulations } \\
\text { Background checks } \\
\text { Waivers responsibility } \\
\text { Privacy concerns }\end{array}$ & \\
\hline
\end{tabular}

In Table 1, we have categorized the public complaints and worries according to their aspects. This reveals that app-based ridesharing companies such as Uber exist in all 15 aspects, although not all aspects are equally important. There exists a number of partners who partake in the app-based network (numerical aspect). The Uber app enables world-wide communication and transportation of passengers (spatial aspect). Uber is assumed to speed up the matching of drivers and passengers, having vehicles quicker at the customer (kinematical aspect). Uber states to be contributing to a more sustainable environment (biotic aspect). Uber heavily relies on proper functioning of telecommunication networks (formative aspect). The use of Uber requires an understanding of pictograms, interactive maps, language, etcetera (symbolic aspect). Uber is built on venture capital (economic aspect). Uber has a user interface that may be designed in a better or worse way (aesthetic aspect). Uber is bound by laws and conventions (juridical aspect). Uber drivers and passengers have a duty to treat one another in a respectful manner (ethical aspect). Trust in the communication technologies and Uber partners is important for an adequate functioning of Uber (pistic aspect). This analysis serves to show how complex the issue of app-based ridesharing companies such as Uber can be. In all of these aspects, problems or norm violations, causing dilemmas, can occur.

\section{Conclusion}

By taking Uber as a case for a business model that is typical for the sharing economy, namely using underutilized goods by private persons that are connected through digital technologies, we showed some of the complexities such novel business models bring about, leading to an array of dilemmas and issues. We listed a number of issues and tensions as they were reported in newspapers and websites and which cause dilemmas for regulators and established industries. We further catagorized and presented them in a table. The categorization was done through a multi-aspectual analysis. It revealed that next to several public com- 
plaints and worries, also other, presumably overlooked aspects, may give rise to moral issues and dilemmas at a deeper level.

One of our findings is that besides the legal issues, Uber may, in contrary to what Uber states about herself, have a negative environmental effect, because Uber may attract people to use their cars more often, rather than less often. Another relevant but overlooked aspect is the importance of the algorithm, which decides who can ride with whom on the basis of design decisions that may be inspired by social, cultural or moral values.

The multi-aspectual analysis is a tool to identify potentially important issues at stake in app-based ridesharing companies that have thus far been outside the focus of critics, scholars and proponents and that may be the key to advancing unease and clashes with Uber. The multi-aspectual analysis may be a fruitful tool for analyzing other sharing economy situations, such as online platforms for sharing guest accommodation. A further analysis is needed that focusses on the relationship between the different entities that are related to Uber's business model, such as governments, insurance companies, taxi unions, environmental organizations etcetera. It can highlight underestimated or neglected issues, especially those that create moral tensions and dilemmas.

References

Adhikari, S., 2015. Taxi industry slams Uber's 20,000 jobs stunt. Technology Spectator, 16 February 2015.

Baker, D., 2014. Don't Buy the 'Sharing Economy' Hype: Airbnb and Uber Are Facilitating Ripoffs, The Guardian, 27 May, 2014.

Bergvall-Kåreborn, B., 2002. Qualifying function in SSM Modeling-A case study. Systemic Practice and Action Research, 15(4), pp.309-330.

Botsman, R., 2015. Defining the sharing economy: What is collaborative Consumption-And what isn't? Retrieved from http://www.fastcoexist.com/3046119/defining-the-sharing-economy-whatis-collaborative-consumption-and-what-isnt.

de Vries, M. J., 2005. Analyzing the complexity of nanotechnology. Techné, 8(3), pp. 62-75.

Edelman, B. G. and Geradin, D., 2015. Efficiencies and Regulatory Shortcuts: How Should We Regulate Companies like Airbnb and Uber? Harvard Business School Working Paper 16-026.

Friedman, T. L., 2013. Welcome to the 'Sharing Economy'. The New York Times, 20 July 2013.

Isaac, M., 2015. A Prickly Partnership for Uber and Google. The New York Times, 8 February 2015.

Kalamar, A. (13 May 2013). Sharewashing is the new greenwashing. Retrieved from http://www.opednews.com/articles/Sharewashing-is-the-New-Gr-byAnthony-Kalamar-130513-834.html 
Kraan, J. and van Hoek, C., 2014. Particulierendienst Uber in Nederland illegaal. Nu.nl, 30 July 2014.

Meelen, T. and Frenken, K., 2015. Stop saying Uber is part of the sharing economy. Retrieved from http://www.fastcoexist.com/3040863/stop-sayinguber-is-part-of-the-sharing-economy.

Munger, M.C., 2015. The Third Entrepreneurial Revolution: A Middleman Economy. Duke University, Department of Political Science. Retreived from http://www.econ.as.nyu.edu/docs/IO/37424/Munger Third Entrepreneurial Revolution2.pdf

Orssatto, R.J. and Clegg, S.R., 1999. The Political Ecology of Organizations Toward a Framework for Analyzing Business-Environment Relationships. Organization \& Environment, 12 (3), pp. 263-279.

Schor, J. and Initiative, G. T., 2014. Debating the Sharing Economy. Great Transition Initiative, October 2014.

Sharma, P., 2015. Uber Ugly Fineprint. Business world, January 14, 2015. Retreived from: http://businessworld.in/article/Uber-Ugly-Fine-Print/14-012015-78304/

Slavnic, Z., 2011. Struggle for Survival in the Deregulated Market: Recommodification and Informalisation of the Taxi Sector in Stockholm. Forum for Social Economics, 40 (2), pp. 233-251.

Smolka, C. and Hienerth, C., 2014. The best of both worlds: Conceptualizing trade-offs between openness and closedness for sharing economy models. 12th International Open and User Innovation Workshop Harvard Business School, Harvard University.

Tam, P. and de la Merced, Michael J., 2015. Uber fund-raising points to $\$ 50$ billion valuation. The New York Times, 9 May 2015. pp. B2.

Weisse, E. and Guynn, J., 2014. Uber tracking raises privacy concerns. USA Today, 19 November 2014.

Witt, A., Suzor, N. and Wikström, P., 2015. Regulating ride-sharing in the peer economy. Communication Research and Practice, 1 (2), pp. 174-190. 